病巢部では, 神経細胞はすべて溶解又は消失し，神経瀻 維，檤鞘も断裂文は消失する・脂肪顆粒細胞は余り見ら れなかつた。

病巢部以外の笑賀では，全般的にミクログリアの反應 が圥進しそそれらの間に少数の多形核白血球が潵在する 箇所々見られる．血管周囲のリンパ腔には，種々の程度 のリンパ球，單核細胞，支び少数の多形白血球より成る 細胞浸潤が見られ，浸潤高度のるのでは，腔を越えて周 囲の楶筫內に侵入する。

延骹中央部の第四脳室に近い部に，軽度の出血が見ら れる.すなわち, 血液がリンパ腔へ湓出し, 更に周用の 笑筫內へ浸潤し，毛細血管では，血液が笑質內へ限界不 明膫に浸潤する。この部分の血管は，一般に血液充盈像 を示す。

病巢部附近の神経細胞は，色々の程度の生活力の減退 を示し，たいていの核は，濃縮像を示すか，又は埧失す る. 組胞筫は腫大又は萎縮し、ニッスル小体は溶解の傾 向を示す。しかし又逆に，ニッスル可染物質が萎縮した 細胞質の一側に濃染するすのがある。

特異な所見として，多形核白血球性の神涩食現参 (Neuronophagie) 像が見られる. 多形核白血球の信入 を受けた神経細胞は，明らかに核か濃縮するか，文は組 䊎となり，ニッスル小体は溶解し，壞死に招ちいつてい ることを示す， 文神経細胞力゙完全に溶解し，その場所 に, 多形校白血球の小さい集簇が置き換わつているのが 見ら対る。神経細胞內に侵入するのは，多形核白血球で あつて，更にその細胞質の周囲に，ミクログリアが增生 する像も見られる。

神経細胞內に侵入した多形核白血球は，核濃縮像を示

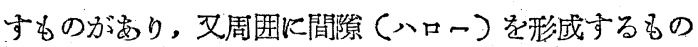
が女り，白血球力瀼死に招ちいつた神経細胞を溶解して いると考えられる。グラム染色で見ると，該神経細胞の 周囲に菌が等つて來ているのが見られる。

かかる多形核白血球性の神経食現像像は，人の急性脊 㭜前角炎 (acute anterior poliomyelitis) の場合炕記
載されているK過ぎないが，SPIGLMETER によれぱ，や はり神経食現象の範瞦に属するものであつて，またネタ ロファギー (Nekrophagie) とも呼えでいる.

軟膜には，大した変化が認められず，僅少の單核細 胞,リンパ球, 多形核白血球の浸潤をこらむつて, 浮腫 性疎開を呈する。

3. グラム染色による所見上述の病巢の內部と, そ れにごく接近した周辺部には，グラム陽性の両端鈍円， わずかに彗曲する的 $0.5 \times 1.2$ ル小桿菌が存在するが, その他の部では，前述の神経食現缘を是する部分の周囲 を除いては，ほとんぞ䭃められない，菌は病巢內で孤立 するか，女るい性 2 個又は数個のものが，それぞれ一端 をるつて連接し，連鎖㹜となる，又概して，多形核白血 球の多い病巢內に多く存在し,グリアの多いところでは 少くなつている。

\section{IV 結訇}

わか漍でり，近年三三の研究者によつて，緬・山羊の リステリア症の存在が注目されるよらになつた。たまた ま我方が1949年秋に遭遇した山羊の剖檢例が, 病理組織 学的に見て,リステリア症の疑が濃くなつて來にのて， 再び詳紬な检討夌加光て見た。

その結果, 本例は, 病理組織学的火見て, Listeria monocytogenes と思わ机る小桿菌によつてひき起され そ化膿性脳炎で，しかも主要病变が脳幹部に限局してい る点は, 先人の記載にほぼ一致して牧り，正しく山羊の ทステリア症と考えら秃るるのである.

な特文多形核白血球性の神経食現象は, 獸医学領域て は新しい所見であると考える。

助言をいただいた家畜衛生試験場の旭技官と，終始指 導を賜わつそ菊池教授に感鲫の意を表する。

\section{参考交 献}

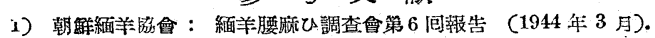

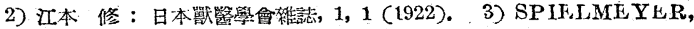
W. : Histopathologie d. Nervensystems, 1 (1922). 4) 須

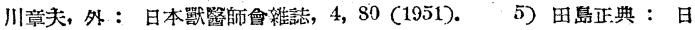

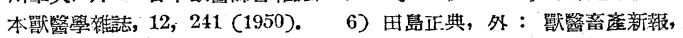

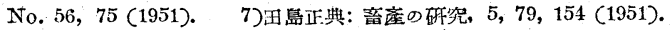

\title{
犬のトキソプラズマ自然感染例について
}

浜田輔一

昭和 22 年 (1947) 9 月末, 札晩で偶然犬のトキソプラ ズマ病の1例を観察する機会を得た。との各種所見は， 本戶1) (1939) が観察した狸に打ける本病に近似してい るが, 犬に新ける本病例は，わが國ではまだ報告されて いないのでそその臨床並びに解剖所見及び原虫の形態に
ついて，簡單に記載したいと思ら。

今日までに特ける，犬の本病関する報告を一覽する そ，1910年イタリー2)で1例の自然感染例か観察された のを㜴矢として，その後ブラジル33)，ドイッ5)，北アフ リカ(BuANC, 1917), フランス6), イラク7), アメリカ8), ・ 
さらに1948年にはスウエーデン9)にも，本病が発生して wる.

\section{臨 床 所 見}

䍜病犬は生後 6 カ月のシェパード純血種の壮で, 昭和 22 年 (1947年) 9 月20日北海道帶廣市內で生饥, 同年 8 月15日灾ら札㹸市內で飼育されるようとなったが，この 間特に取り上げるような病歷はない。

8 月 27 日ごろから，両眼より軽度の膿性眼淢を漏らし

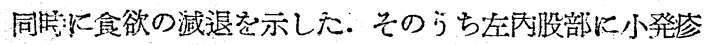

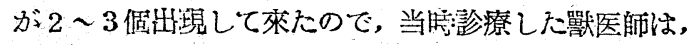
ジステンパーの疑をもち，9月1日サルファ剤を靜注す

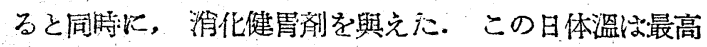
$39.2^{\circ} \mathrm{C}$ であり, 眼結膜は充血し, 眼㖑を附着していた。

その後 2,3 日の経過と共に, 內股部の小発疹は消失 し，元篓食欲も次第に增進してきた。しかし 9 月13日朝 心ら再び食欲が低下し，15日朝に至つて全く廃絶，嘔吐 む認忨られた。同日夜林榣汗を少量摆取したが，16日朝 下はこれを昍出し，艾下痢が認められふ。体溫は $39.7^{\circ} \mathrm{C}$ ーでるるが, 鼻端, 耳端, 四肢末端等は冷却した。 エルス チンを注射・聽診上，盿炎の定候はないが，呼吸荒く， 乙ふる苦悶の狀を呈するので,デルモライツ及びアルコ

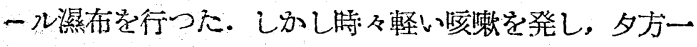

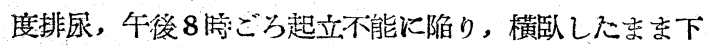
痢し，その後20分で絕命した.

結局，本犬は 8 月27日ごろ発病し，経過惊一转好轉す るよらに見えふが，急变して逐に9月16日夜，約20日間 の経過で整死したすのである。

以上の病例て観察した食欲不浱, 嘔吐, 下浲, 呼吸困

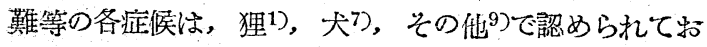

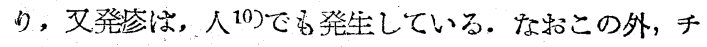
ンチラ11に凯ける本病で, 生後 8 方月以上のものに永続 性の膿性悬漏を認めえこと, 交び幼若なるのでは病性の 経過が急であり, 体の本衡維持不能, 運動失調, とんぼ がえり，両側反轉等の称経症侯を表わして，多くば死の 轉㷌をとつたことが報告されているが，本例では，加名 る触経症候は全く認められなからた。

\section{解 剖 所 見}

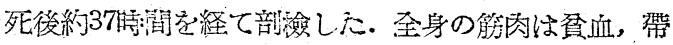
黄, 溷濁し，腹水沙血樣であるが，洔に增量はしていな

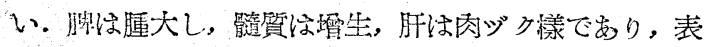
面友び筫內には，針頭大ないし覃粒太の灰白小斑点が 少数散在する。胆霆は少しく膨満し, 內に濃厚粘稠な胆 汁を满にす。腎は萊膜の制離容易，皮筫部に栗粒大の 灰白小斑点少数存在，笑筫は中等度に润濁嘲脤与る。

胃は活とんど內容なく，粘膜はカタール性である。小 腸も大体局樣の変状であるが，空腸及び回腸に执いて， カターールガ特に高度である.胸水やや霄量, 左肺法中等

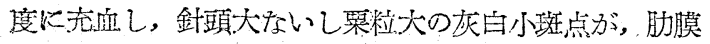

下のみならず內部実筫內にも多数存在し，汃る灰白小 斑点は, 右肺にも相当数認めら机た。脳は著変がない。

要するに解剖学的診断は，(1) 肺，肝及び留に特ける 針頭大ないし栗粒大の小結節狀壇死巢，(2) 空渴及び回 晹の高度カターー，(3) 軽度の肺充血並びとカタール性 肺炎等である。

以上の各病変ば、いずれる前記各報告の記載と一致し ている.この活か，羊，猫, 犬8)で小搨及びリンパ節の

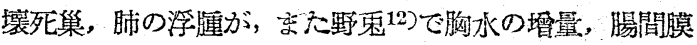
ソンパ節の腫大证びに壊死巢が, 叉スウエーデン9では 犬で腸間膜りンパ節の栗粒大病巢並びそ胃及び国腸の潰

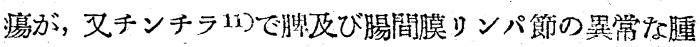
大並びに肺の出血が，それぞれ観察されている点より， 剖檢の際は，かかる所見飞る注目すべきであむろう。

なお本病例の病理組織所見を簡單飞还べると, 肝, 肺, 蜰等に不完全壤死巢及び壇死巢か認められる活か火，肝 小莧內の壞死集周囲の肝細胞內に虫体分废在する. 又肺 は裂血が高度であり，且つ一般飞軽い細胞浸閵があつ て，良食細胞，多形核白血球リンパ㨾細胞等が認めら れる。壤死巢周再飞は，特別の反應層はない。胃，大小 腸等の消化管は, 死後の変化か浊く, 病変は明らかでな い. 膀脱は，粘膜下織の節血があるが，粘膜上皮には異

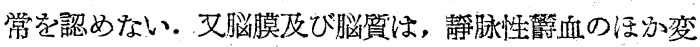
化を認めない。

以上の所見のうち，膀胱及び脳筫の所見から，一隹ジ ステンパーは否定し得る. しかし奻兒のトキソプラズマ

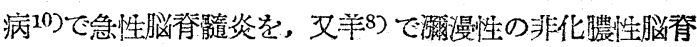
骼炎を認めにといら報告があるから，万一犬でかかる所 見が活現した場命火は，ジステンパーとの類昰鑑別に十 分な注意を必要とするであうう。

\section{塗床標本における原虫の形態}

望抹標本を鏡檢して, 初めて本原虫の存在を確認し た. 標本は，型の如くメチルアルコール固定後, ギムザ 染色を施したものである.虫体の数は肺, 㹸に多く、穴

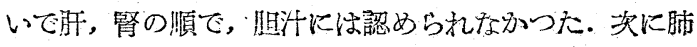
の標本に纱汗る本虫の形態を远べる。

虫体は單一て細胞外に避離しているるの乃㵊も多い。 これらは (1) 細い三日月型(第1园1)，（2）太つた

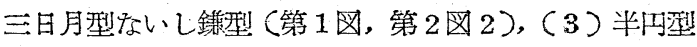

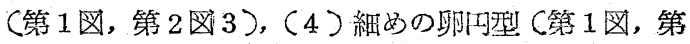

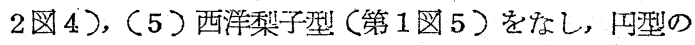
ものは認められない（4) 更び（5）のような形態で

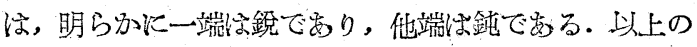
形の5ち，最も多く認められたるのは（4）の卵们

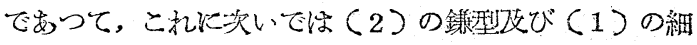
い三日月型である。な蛙体の膨隆したもので，原形筫

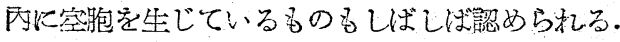

原形質は一譐に薄桃色に染末るものが多いが，中には 


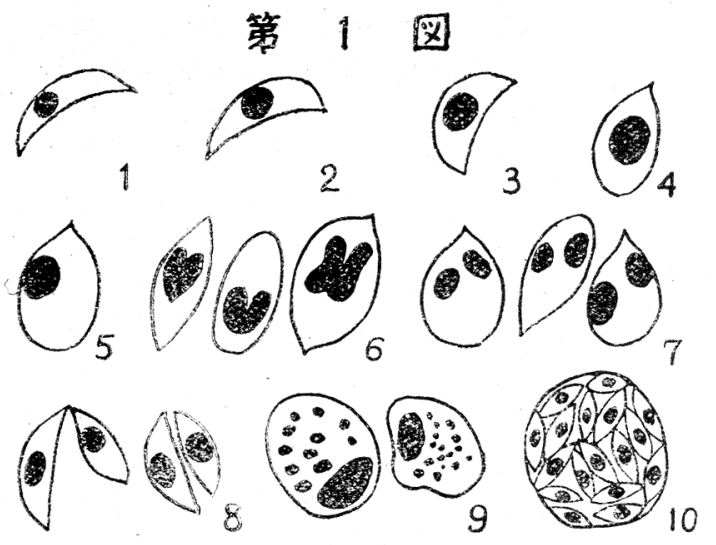

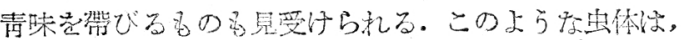

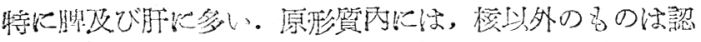
められない。樹经问形ない儿棈四形のものが1個存し， その位置は一定しない。色恃紫色を呈する。

虫体の大きさ惊，定型的形態を有する1，2更び4 型

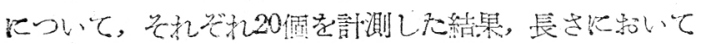

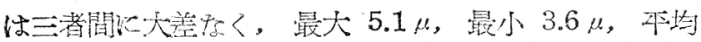

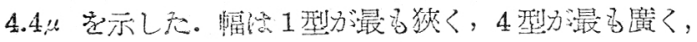
とれらの籁用は 1.4 3.6\%で岕つ充。

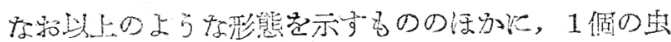

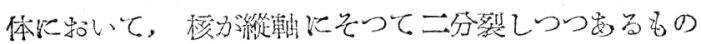
(第 1 图6)，2侽の核以分机 ているるの第1园7〕，更に 原形筫之二分した。の(第 1

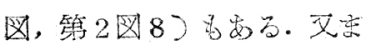

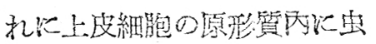
体分集国して疗在することが

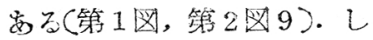

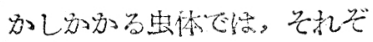

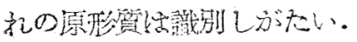
又虫体の唃生した細胞は，核

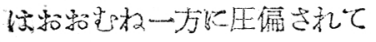
萎縮し, 又細泡全体の限界が

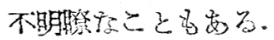

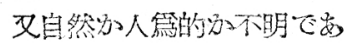
るが，㤁㣻る細胞品ら，虫体 が密さと遊出しようとするよ

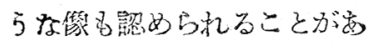

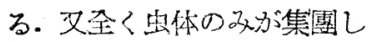
て，1㨐の球艺形成している ものむ，昰机比認められ(第 1 区、第 2 図 10), 虫体数の

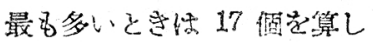
Æ. と机ら虫体の等團它包む

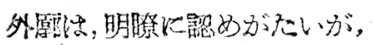

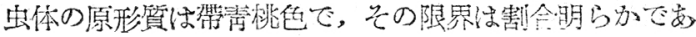

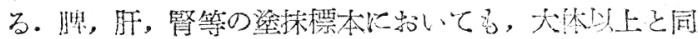
稳厄效つ庆。

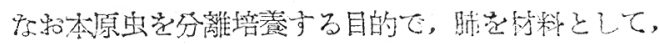

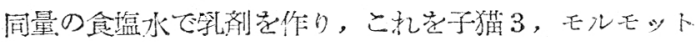

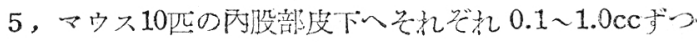
接種したが，本原虫に上る感染発底は久られなか心。

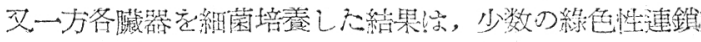
狀球菌及び、大場菌足殓低した。

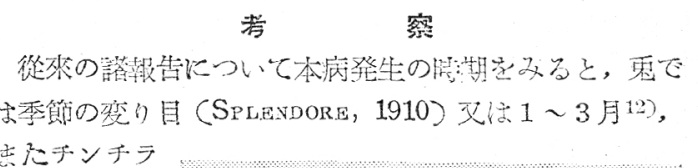
で7月初旬 11 ヤマアラシで は $10 \sim 2$ 月 (Сн.ттов \& Blane, 1917) 犬で怯 4月7) 狸で结 6 月11 とい5爿況て 多。文本例 て综8月下旬 で岁るから。 第 2 目（いずれる ×2400)
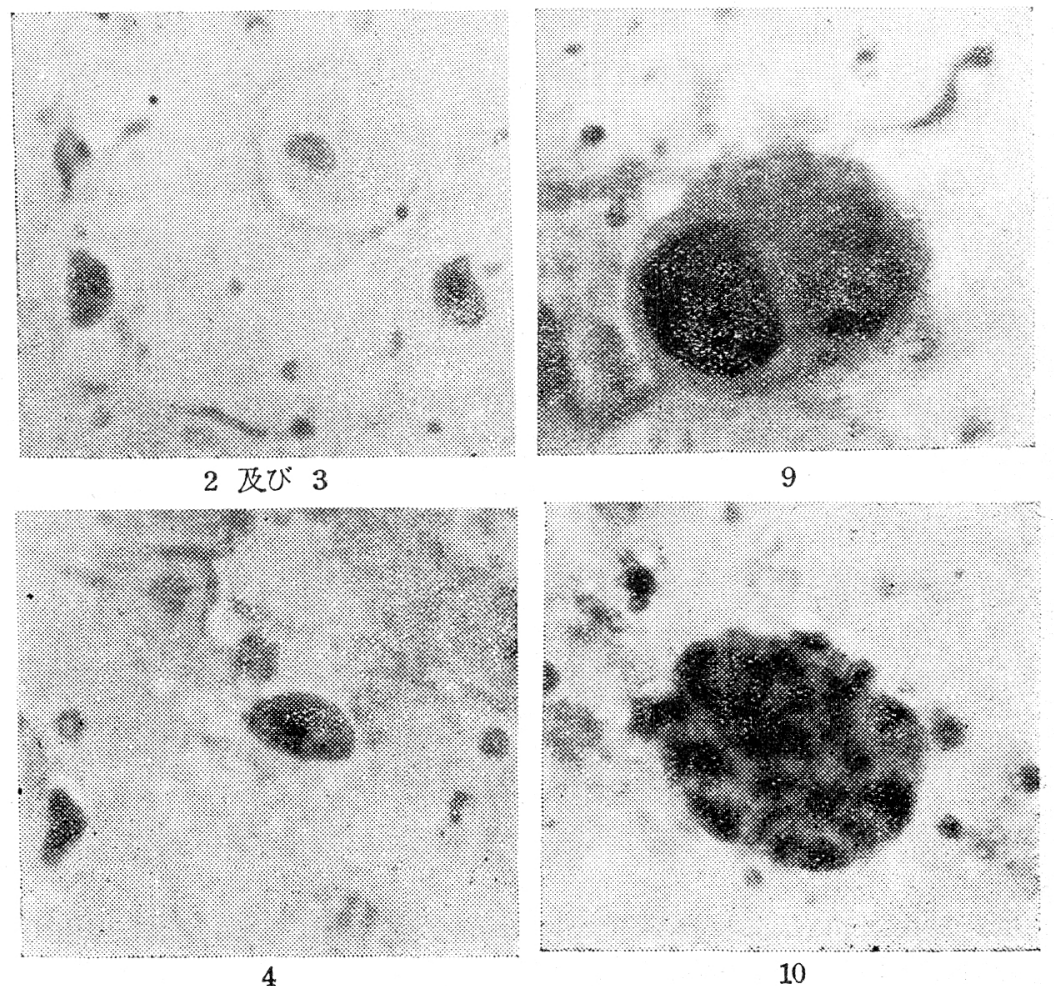
本病について, 特定の感染特期は認められない。

次に Chatron ら (1917)は最初飼育したヤマアラシ に本病を発見し; さらに 400 頭の野生のャマアラシにつ いて检菜したが，本虫が発見できなかつた，又バグダッ ドてでは野犬が多いのKかかわらず，飼育者を異にする 2 頭の畜犬が，偶然 2 週間の內に本病で連続獘死してい る.わ力國1のある麺狸場で，多数飼育されていた狸の 中から，これまた 2 週間の內に続いて整死した2頭に括 いて本虫を発見した，亦た私の例!ま，特に注意して熬留

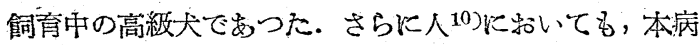
の子宮內感染と思われる流產胎兒例を倠察している.こ れらの事余から，本病の発生機轉は偶発的のるののよう でまり，その感染要約は不明である。

しかしながら、本原虫は,1908年 NICOLLE \& M.ANCE.AUX により，北アフリカのチュニスで,ヤマアラシから発見 されて以來, 人, 猿, 小肉食動物, 鮘類, 蛇類等でも認 められてはいるが，觜函類及び鳥類から発見された煬合 济洺.

與昧をる報告を摘記すると，野鼠13)の感染率は $8.7 \%$ であり，1935１947年にわたつて総計 2,411 牙の野秋12) のちち，211㭁(8.8\%) K本虫を检出している. 㕛チンチ ラ11)に拈ける流行の原因が，恐らく鳥類か踾茵類である 弛といら報告は、はなはだ当を得ているよらに思われる。 な和本病は，臨床並びに病理解剖所見から見ると、ジ
ステンパー，もしくはパラチフスとよく類似した疾患で あるが，病原体の䌞出及び病理組織所見によつて，容易 に類泟鑑別ができる.

\section{結}

札幌で観察した犬のトキソプラズマ病1例は，さきに 札幌で本戸が報告した狸のトキソプラズ、病と共に，國 內に哇ける本原虫の自然感染例としては，稀有なるもの に属する.たもた狸と犬の病例が，いずれも札㹸で観 察されたが，他の地方，むた他の動物にも，当然その存 在が推測されるのである。ここに臨床家の注意を喚起 し，今後に㟧ける細密な観察を期待したい。

指等と校閲を賜わつた平戸教授に謹謝し，材料を提供

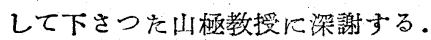

(北海滇大学裳学部家畜衛生学呚室 主在: 本戶呚授)

\section{文献}

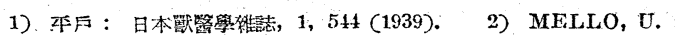
Zbl. Bakt., Ref., 48, $616(1910)$. 3) CARINI, A. : Ibid., 52, 132 (1912).4) CARINI, A. \& MACIEL, J. : Ibid., 60, 543 (1913). 5) YAKIMOFF, W. I. \& YAKIMOFF, N. K. : Arch. Protistenk., 27, 195 (1912). 6) NICOLAU, S. \& KOP CIOWSKA, L. : Zzbl. Bakt., Ref., 120, 19j (1935-36).

7) NACHATTIE, C. : Vet. $J ., 95,70(1939) .8$ 8) OLAFSON, P. \& MONLUX, W. S. : Ref., Exp. Stat. Rec., 87, 567 (1942). 9) KARLSON, A. G. (abstracting): J. Amer. Vet. Med. Ass., 113, 181 (1948). 10) M.ANTZ, F. A. et al. : Amer. f. Trop. Med., 29, 895 (1949). 11) KEAGY, H. F.: $J$. Amer. Vet. Med. Ass., 114, 15 (1949). 12) CHRISTIANSEN, M. : Ref., Ibid., 113, 79 (1948). 13) PERRIN, T. L. $e t$ al. : Ref., Exp. Stat. Rec., 89, 361 (1943).

がある，血管內皮，脳膜，網狀織細胞，肝細胞㭙儿副腎 皮質細胞に核內封入体をみる。

著者らはかかる相似性に着目し，両病毒が免疫学的に 同じかどらかしらべようとした. その術式は，Evarsら の方洗に從い，前眼房に接種する. その結果, 大肝炎病 毒及び狐脳炎病毒は，10-8の稀釈度で同じような感染力 を示した。

細胞封入体は，在膜內壁の內皮細胞に見られ，形態学

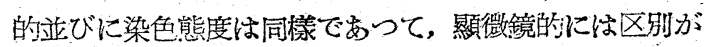
つかない大肝炎病寈及び狐脳炎血清をくりかえし注射 乙て得㚘血淸は, 犬肝炎及び狐脳炎病毒を，等しくよく中

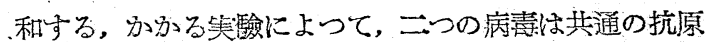
性を持ち，同㥞の病毒として考㝋てよいことがわから た. その点 RUBARTH の原著に対比して，興味のある成 績といわねばならぬ.

抗脳炎性血清をアメリカ各地の獸医師が野外試驗した

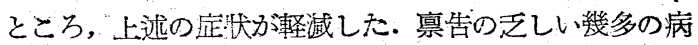
例に於ても抗血清の使用によつて，24㭙盟以內に症狀の 完奎治癔を見たものがしばしばあうた。(市川) SIEDENTopF, H. A. \& C.ARLson, W. E. : A comparative study of the fox encephalitis virus and the virus of infectious canine hepatitis. J. Amer. Vet. Med. Ass., 115 (No. 869), 109 (1949). 